\title{
Topical Application of Doxycycline Inhibits Th2 Cell Development Mediated by Langerhans Cells and Exerts a Therapeutic Effect on Atopic Dermatitis
}

\author{
Katsuhiko Matsui, Yuki Nojima, Yuka Kajiwara, Kana Busujima, Yuki Mori. \\ Department of Clinical Immunology, Meiji Pharmaceutical University, Tokyo, Japan. \\ Received, December 24, 2019; Revised, April 14, 2020; Accepted, April 17, 2020; Published, April 21, 2020.
}

\begin{abstract}
Background: Langerhans cells (LCs) polarize the immune milieu towards a T helper type (Th) 1 or Th2 immune response. We investigated the effects of selected tetracyclines on Th cells development mediated by LCs, and their implications for the treatment of atopic dermatitis (AD). Methods: Mice were primed with ovalbumin (OVA) peptide-pulsed LCs, which had been treated with each antibiotic, via the hind footpad. After 5 days, the Th1/Th2 cytokine response in the popliteal lymph nodes was investigated by enzyme-linked immunosorbent assay. The expression of cell surface molecules on LCs was investigated using reverse transcriptase polymerase chain reaction. The therapeutic effects of a selected antibiotic on AD-like skin lesions of NC/Nga mice were assessed in terms of the skin severity score, histological changes in the lesioned skin, the serum level of total IgE, and expression of Th1/Th2 cytokines in lymph nodes and skin lesions. Results: Antibiotic-treated, OVA peptide-pulsed LCs inhibited development of Th2 cells but not Th1 cells. This was accompanied by suppression of T-cell immunoglobulin and mucin domain-containing protein (TIM)-4 expression in LCs. Doxycycline had the greatest activity against Staphylococcus aureus strains isolated from skin lesions of patients with $\mathrm{AD}$, and a strong inhibitory effect on Th2 cell development. Doxycycline suppressed the increase in the skin severity score during the acute phase in NC/Nga mice similar to betamethasone. This suppressive effect was associated with a decrease in the serum IgE level and production of Th2 cytokines in auricular lymph node cells and skin lesions. Conclusion: Topical application of doxycycline to AD lesions would act on both superficial $S$. aureus colonization and epidermal LCs, thus possibly inhibiting the development of Th2 cells in vivo, with benefits for control of acute inflammation in AD.
\end{abstract}

\section{INTRODUCTION}

Atopic dermatitis (AD) is a chronic inflammatory skin disease with immunopathologic features that vary depending on the duration of the lesions. Most AD patients show superficial skin colonization by Staphylococcus aureus and increased expression of T helper type 2 (Th2) cytokines such as interleukin (IL)-4, IL-5 and IL-13 in their peripheral blood mononuclear cells (1). S. aureus can be isolated from $96-100 \%$ of AD skin lesions, whereas only $0-10 \%$ of healthy individuals show skin colonization by this organism $(2,3)$. We have also found that in $\mathrm{AD}$ patients $S$. aureus is detectable in the lesioned skin at a higher frequency than in non-lesioned skin, and that the $S$. aureus bacterial cell count is significantly higher in the former than in the latter (3). Furthermore, we have recently demonstrated that chronic skin colonization by $S$. aureus may augment Th2 cell development in AD patients (4-6). Therefore, treatment with antibiotics may be beneficial for $\mathrm{AD}$ patients, not only in those with impetiginized $\mathrm{AD}$ but also those without clinical signs of superinfection.

Langerhans cells (LCs) are a subpopulation of bone marrow-derived dendritic cells (DCs). They are antigen-presenting cells (APCs) capable of internalizing and processing antigen (7). Because they reside in the epithelium of skin and mucosal membranes, they may be the primary target cells for antigens entering the skin, oral mucosa and airways (8-11). After antigen uptake they migrate to regional lymph nodes where peptides, in the context of major histocompatibility complex (MHC) class II molecules, are presented to Th cells with appropriate Th cell receptors. This first signal to Th cells, together with a second signal, delivered in part by interaction between the CD80 and CD86 molecules on LCs and CD28 on Th cells, results in activation of Th cells $(12,13)$.

Corresponding Author: Katsuhiko Matsui, Ph.D.; Department of Clinical Immunology, Meiji Pharmaceutical University, 2-522-1 Noshio, Kiyose, Tokyo 204-8588, JAPAN. E-mail:kmatsui@my-pharm.ac.jp 
Furthermore, LCs work as primary orchestrators in the polarization of immune responses towards a Th1 or Th2 milieu. The nature of the polarization is influenced by a number of factors and in particular, development of Th 2 cells, producing Th 2 cytokines, plays pivotal roles in inducing allergic inflammation (14). Therefore, allergic inflammation may be controlled through the regulation of LCs. In our previous study, we succeeded in generating LCs from murine bone marrow and developing Th1 cells or Th2 cells using the LCs (15). Although it is known that tetracycline antibiotics have immunomodulatory effects in addition to their bactericidal activity (16), it is unclear whether they inhibit Th2 cell development mediated by LCs. In this study, we investigated the effects of tetracycline antibiotics on LCs in the context of Th2 cell development, and evaluated the effect of topical application of a selected antibiotic on AD-like skin lesions in NC/Nga mice.

\section{MATERIALS AND METHODS}

\section{Mice}

Specific-pathogen-free BALB/c (wild type) mice, DO 11.10 TCR Tg mice $\left(\mathrm{OVA}_{323-339}\right.$-specific I-A ${ }^{\mathrm{d}}$ restricted TCR-transgenic mice) and $\mathrm{NC} / \mathrm{Nga}$ mice were obtained from Japan SLC (Hamamatsu, Japan), The Jackson Laboratory (Bar Harbor, Maine, USA) and Japan SLC, respectively, and used at the age of 8 weeks. They were housed in plastic cages with sterilized paper bedding in a clean, air-conditioned room at $24{ }^{\circ} \mathrm{C}$ and allowed free access to a standard laboratory diet and water. All procedures performed on the mice were in accordance with the Guidelines of the Animal Care and Use Committee of Meiji Pharmaceutical University, Tokyo.

\section{Antibiotics}

Tetracycline hydrochloride, oxytetracycline hydrochloride, demethylchlortetracycline hydrochloride, doxycycline hyclate and minocycline hydrochloride were purchased from Sigma-Aldrich (St. Louis, MO, USA).

\section{Generation of LCs}

The preparation and culture of bone marrow cells from mice to generate LCs were performed as described previously (15), with modification. Briefly, bone marrow cells from BALB/c mice were cultured in RPMI 10 (RPMI 1640 medium with Lglutamine (Sigma-Aldrich) containing 10\% fetal bovine serum (Sigma-Aldrich), $25 \mathrm{mM}$ Hepes
(Sigma-Aldrich), $100 \mathrm{U} / \mathrm{mL}$ penicillin and 100 $\mu \mathrm{g} / \mathrm{mL}$ streptomycin (Gibco RBL, Grand Island, NY, USA)) supplemented with recombinant murine GMCSF (20 ng/mL; PeproTech, Rocky Hill, NJ, USA), recombinant murine IL-4 (100 ng/mL; PeproTech) and recombinant human TGF- $\beta 1 \quad(10 \mathrm{ng} / \mathrm{mL}$; PeproTech) at $37{ }^{\circ} \mathrm{C}$ in a humidified atmosphere with $5 \% \mathrm{CO}_{2}$. Half of the total volume of the culture medium was changed every $48 \mathrm{~h}$, and 7 days after the beginning of culture, the grew cells were treated with mouse anti-mouse I-A ${ }^{\mathrm{d}}$ monoclonal antibody (clone 34-5-3s, mouse IgG2a) (final concentration 1:200; Cedarlane Laboratories, Ontario, Canada) in RPMI 10 for $1 \mathrm{~h}$ on ice. The cells reacted with antiI-A ${ }^{\mathrm{d}}$ antibody were then purified using a CELLection Pan Mouse IgG Kit (Invitrogen Dynal AS, Oslo, Norway) and used as LCs. LCs, I-A positive cells were purified to around $95 \%$ purity as determined by flow cytometry.

\section{Th1 Cell and Th2 Cell Regulation by Antibiotic- Treated LCs}

Th1/Th2 regulation by LCs was investigated as described previously (17). Briefly, LCs were adjusted to $2 \times 10^{5}$ cells $/ \mathrm{mL}$ in RPMI 10 and then incubated with $6 \mu \mathrm{M}$ OVA peptide (323ISQAVHAAHAEINEAGR-339; obtained from Operon Biotechnologies, Tokyo, Japan) in the presence or absence of 5 and $50 \mu \mathrm{M}$ each tetracycline antibiotic at $37^{\circ} \mathrm{C}$ in a humidified atmosphere with $5 \% \mathrm{CO}_{2}$. The cells were collected after incubation for $18 \mathrm{~h}$, washed in RPMI 10, and administered at a dose of $5 \times 10^{4}$ cells into both hind footpads of DO 11.10 TCR Tg mice. After 5 days, popliteal lymph nodes were harvested and adjusted to $1 \times 10^{6}$ cells $/ \mathrm{mL}$ in RPMI 10 . The cultures $(0.2$ $\mathrm{mL} /$ well) were incubated in 96-well culture plates (Nunc, Roskilde, Denmark) in the presence of Dynabeads Mouse T-Activator CD3/CD28 (5 $\mu \mathrm{L} /$ well; Life Technologies, Oslo, Norway) at $37^{\circ} \mathrm{C}$ in a humidified atmosphere with $5 \% \mathrm{CO}_{2}$. The culture supernatants were collected after incubation for $48 \mathrm{~h}$, and the interferon (IFN)- $\gamma$ and IL-4 concentrations were measured using enzyme-linked immunosorbent assay (ELISA) kits for quantification of murine IFN- $\gamma$ and IL-4, respectively (R \& D Systems, Minneapolis, MN, USA).

Reverse Transcription-Polymerase Chain Reaction Assay (RT-PCR)

In order to determine the levels of mRNA expression 
for various cell surface molecules, mRNA was extracted from LCs $\left(1 \times 10^{5}\right.$ cells) using Dynabeads mRNA DIRECT Micro Kit (Life Technologies, Oslo, Norway), and also to determine the levels of expression of IFN- $\gamma$ and IL-4 mRNA in auricular lymph node cells and dorsal skin lesions, total RNA was extracted from each by the single-step method using TRI-Reagent (Molecular Research Center, Cincinnati, OH, USA). Then, the cDNA was synthesized from $160 \mathrm{ng}$ of the mRNA or $2 \mu \mathrm{g}$ of the total RNA using a first-strand cDNA synthesis kit (GE Healthcare UK, Little Chalfont, Buckinghamshire, UK). PCR was performed using the following primers: $\beta$-actin $(540 \mathrm{bp}) 5^{\prime}$ primer, $5^{\prime}$ GTGGGCCGCTCTAGGCACCAA-3' and $3^{\prime}$ primer, 5'-CTCTTTGATGTCACGCACGATTTC-3'; Jagged $1 \quad(314 \quad$ bp) 5' primer, 5'ATCCGAGTGACCTGTGATGA-3' and 3' primer, 5'-TTGGTCTCACAGAGGCACTG-3'; Jagged 2 $\left(\begin{array}{llll}300 & \text { bp }) & 5 & \text { primer, } \\ 5^{\prime}-\end{array}\right.$ GCTGTGATGAGAACTACTAC-3' and 3' primer, 5'-TCTCACAGTCACAGTGCCAG-3'; T-cell immunoglobulin and mucin domain-containing protein (TIM)-4 (304 bp) 5' primer, 5'GTCCAGTTTGGTGAAGTGTC-3' and 3' primer, 5'-ACGTGGTCACTGCTGTACTG-3'; IFN- $\gamma$ (405 bp) $\quad 5^{\prime}$ primer, 5'GCTACACACTGCATCTTGGCTTTG-3' and $3^{\prime}$ primer, 5'-CACTCGGATGAGCTCATTGAATGC3'; IL-4 (400 bp) 5' primer, 5'AGTTGTCATCCTGCTCTTCTTTCTC-3' and $3^{\prime}$ primer, $5^{\prime}-$ CGAGTAATCCATTTGCATGATGCTC-3'. Each PCR was performed using a GeneAmp PCR System 9700 (Perkin-Elmer, Norwalk, CT, USA) in $25 \mu \mathrm{L}$ of reaction mixture comprising $1.5 \mu \mathrm{L}$ cDNA (corresponding to $16 \mathrm{ng}$ of mRNA starting material or $200 \mathrm{ng}$ total RNA starting material), $200 \mu \mathrm{M}$ deoxynucleotide triphosphate mixture, $400 \mathrm{nM}$ each PCR primer and $25 \mathrm{U} / \mathrm{mL}$ Ex Taq DNA polymerase (Takara, Shiga, Japan). The reaction conditions were as follows: one 4-min cycle at $94{ }^{\circ} \mathrm{C}, 35$ cycles comprising $45 \mathrm{~s}$ at $94{ }^{\circ} \mathrm{C}, 45 \mathrm{~s}$ at $61{ }^{\circ} \mathrm{C}$ and $2 \mathrm{~min}$ at $72{ }^{\circ} \mathrm{C}$, followed by one 7 -min cycle at $72{ }^{\circ} \mathrm{C}$, and the PCR products were separated on a $2 \%$ agarose gel containing ethidium bromide.

\section{Antibiotic Sensitivity Test}

S. aureus strains were isolated from the lesional skin of AD patients and the antibiotic sensitivity of each $S$. aureus strain was measured as minimum inhibitory concentration (MIC). The MIC of each antibiotic was determined by the broth microdilution method using Mueller Hinton broth, as recommended by the Japanese Society of Chemotherapy.

\section{Topical Application of Doxycycline to NC/Nga} Mice with AD-Like Skin Lesions and Measurement of Skin Severity Score

AD-like skin lesions were produced in NC/Nga mice and the therapeutic effects of doxycycline were assessed by measurement of the skin severity scores, as described previously (18). Briefly, the abdominal hair of NC/Nga mice was shaved, then $100 \mu \mathrm{L}$ of $5 \%$ 2, 4, 6-trinitrochlorobenzene (TNCB) dissolved in an ethanol and acetone mixture (4:1) was applied topically to the abdominal skin $\left(80 \mu \mathrm{L} / 8 \mathrm{~cm}^{2}\right.$ skin) and hind footpads (10 $\mu \mathrm{L} /$ each footpad). Four days after sensitization, the dorsal side of the ears $(10$ $\mu \mathrm{L} /$ each ear) and the shaved dorsal skin $(80 \mu \mathrm{L} / 8$ $\mathrm{cm}^{2}$ skin) were challenged with $100 \mu \mathrm{L}$ of $0.8 \%$ TNCB dissolved in an olive oil and acetone mixture (4:1). After the first challenge, $0.8 \%$ TNCB was repeatedly applied to the same area of the skin a further 5 times at intervals of 1 week. After 4 days of the second $0.8 \%$ TNCB challenge, vehicle, $0.1 \%$ $(\mathrm{w} / \mathrm{w})$ betamethasone ointment and $0.1 \%(\mathrm{w} / \mathrm{w})$ doxycycline ointment were applied topically to the dorsal side of the ears and the dorsal skin (50 $\mathrm{mg} /$ body [ $\left.\left.=50 \mathrm{mg} / 10 \mathrm{~cm}^{2} \mathrm{skin}\right]\right)$ in each group once per day for a total of 29 days. TNCB and betamethasone were purchased from Tokyo Chemical Industry (Tokyo, Japan). White petrolatum including $5 \%(\mathrm{w} / \mathrm{w})$ liquid paraffin was used as the vehicle, and betamethasone ointment and doxycycline ointment were prepared. The drug concentration in ointments was equal to that used in clinical practice. The severity of dermatitis was assessed macroscopically according to the scoring system described below. One skin lesion on each ear, and one on the back, were scored on the basis of the following criteria. The dermatitis score (minimum 0 ; maximum 30 [ $=3$ regions $\times 2$ points $\times 5$ symptoms $]$ ) was defined as the sum of the individual scores for the three regions, and graded as 0 (no symptoms), 1 (less than $1 / 3$ of the skin area) or 2 (1/3 and more of the skin area), for each of the following 5 symptoms: redness/scratch marks, edema/lichenification/ thickening, hemorrhage/scabbing, erosion, and desquamation.

\section{Histopathological Observations}

The dorsal skins of NC/Nga mice were removed 29 days after assessment of skin severity, fixed in $4 \%$ 
paraformaldehyde, embedded in paraffin, and sectioned at a thickness of $5 \mu \mathrm{m}$. Tissue sections were then stained with hematoxylin-eosin (HE) and toluidine blue (TB), respectively, and observed microscopically.

\section{Measurement of Serum Total IgE Levels}

Blood specimens were collected from the heart of $\mathrm{NC} / \mathrm{Nga}$ mice 29 days after assessment of skin lesion severity. The concentration of total IgE in serum was measured using an ELISA kit (Cedarlane, Ontario, Canada).

Quantification of Th1 and Th2 Cytokine Production from $T$ Lymphocytes in Lymph Nodes of NC/Nga Mice

Auricular lymph node cells of NC/Nga mice were harvested on the 29th day of assessment of skin severity, and adjusted to $1 \times 10^{6}$ cells $/ \mathrm{mL}$ in RPMI 10 . The cultures $(0.2 \mathrm{~mL} /$ well $)$ were incubated in $96-$ well culture plates (Nunc) in the presence of Dynabeads Mouse T-Activator CD3/CD28 (Life Technologies, Oslo, Norway) at $37^{\circ} \mathrm{C}$ in a humidified atmosphere with $5 \% \mathrm{CO}_{2}$. The culture supernatants were collected after incubation for $48 \mathrm{~h}$, and the IFN- $\gamma$ and IL-4 concentrations were measured using ELISA kits (R \& D Systems).

\section{Immunohistological Analysis}

Immunohistochemical staining for IFN- $\gamma$ and IL-4 was performed on sections of dorsal skin from NC/Nga mice at 29 days after assessment of skin severity. The skin specimens were embedded and frozen with OCT compound (Miles, Elkhard, IN, USA) at $-80{ }^{\circ} \mathrm{C}$. Frozen sections cut at a thickness of $6 \mu \mathrm{m}$ were fixed in cold acetone $\left(-20^{\circ} \mathrm{C}\right)$ for 10 min, treated with blocking buffer $(10 \%$ normal rat serum in PBS), and incubated with biotinylated rat anti-mouse monoclonal antibodies against IFN- $\gamma$ (clone XMG1.2, IgG1) or IL-4 (clone BVD6-24G2, IgG1) (Bio-Rad, Hercules, CA, USA) at a dose of 2 $\mu \mathrm{g} / \mathrm{ml}$. After being washed with PBS, the skin sections were incubated with peroxidase-conjugated streptavidin (Dako, Carpenteria, CA, USA). Endogenous peroxidase activity was blocked by incubation for $30 \mathrm{~min}$ with $0.3 \%$ hydrogen peroxide in PBS. Endogenous biotin was blocked by sequential incubations with avidin (Vector Laboratories, Burlingame, CA, USA) and biotin (Sigma-Aldrich). The tissue sections were stained by incubation in a solution of 3, 3'-diaminobenzidine tetrahydrochloride (Sigma-Aldrich) and treated with methyl green solution for visualization of nuclei.

\section{STATISTICAL ANALYSIS}

The data were expressed as means $( \pm$ SD), and differences between means were analyzed by the Tukey-Kramer multiple comparison test. Differences at $P<0.05$ were considered to be statistically significant.

\section{RESULTS}

Effects of Tetracycline Antibiotics on Th1 Cell and Th2 Cell Development through LCs

LCs were pulsed with OVA for $18 \mathrm{~h}$ in the presence or absence of tetracycline, oxytetracycline, demethylchlortetracycline, doxycycline, and minocycline, respectively. The LCs were washed and injected into the hind footpads of DO 11.10 TCR $\mathrm{Tg}$ mice, and popliteal lymph node cells were harvested 5 days later. Subsequently, T-lymphocytes among the lymph node cells were stimulated for 48 $\mathrm{h}$ through surface $\mathrm{CD} 3 / \mathrm{CD} 28$ molecules, and the concentrations of IFN- $\gamma$ and IL-4 in the culture supernatants were determined by ELISA. As shown in Figure 1, all of the LCs treated with tetracycline antibiotics induced inhibition of $\mathrm{Th} 2$ cell development in a dose-dependent manner as represented by suppressed IL-4 production. However, levels of inhibition of Th2 cell development induced by tetracycline- and oxytetracycline-treated LCs were slightly less than those induced by demethylchlortetracycline-, doxycycline- and minocycline-treated LCs. Furthermore, Th1 cell development was not influenced by any of the tetracycline antibiotics, as represented by constant IFN- $\gamma$ production.

\section{Effects of Tetracycline Antibiotics on mRNA} Expression of Cell Surface Molecules of LCs

Subsequently, in order to clarify the mechanisms of Th1/Th2 regulation through tetracycline antibiotictreated LCs, LCs were pulsed with OVA for $18 \mathrm{~h}$ in the presence or absence of tetracycline, oxytetracycline, demethylchlortetracycline, doxycycline, and minocycline, respectively, and expression of mRNA for the cell surface molecules Jagged 1, Jagged 2, and TIM-4 was investigated using RT-PCR. As shown in Figure 2, LCs treated with demethylchlortetracycline, doxycycline, and minocycline, respectively, strongly inhibited the expression of TIM-4 mRNA. However, the levels of inhibition of TIM- 4 mRNA expression induced by 
tetracycline- and oxytetracycline-treated LCs were slightly less than those induced by demethylchlortetracycline-, doxycycline- and minocycline-treated LCs. In contrast, expression of Jagged 1 and Jagged 2 mRNA was not influenced by any of the tetracycline antibiotics.

\section{Susceptibility of $S$. aureus Strains to Tetracycline Antibiotics}

The susceptibility of $S$. aureus strains isolated from the lesional skin of AD patients to tetracycline, oxytetracycline, demethylchlortetracycline, doxycycline and minocycline, respectively, was also investigated and compared with that to gentamicin. Figure 3 shows that all of the $S$. aureus strains (33 strains) were strongly susceptible to doxycycline, whereas they were largely insensitive to gentamycin, and the antibacterial activity of the other 4 antibiotics was lower than that of doxycycline.

\section{Therapeutic Effects of Topical Application of Doxycycline on TNCB-Induced AD-Like Skin Lesions}

Assessment of skin lesion severity in NC/Nga mice sensitized with 5\% TNCB was started 4 days after the second challenge with $0.8 \%$ TNCB. The clinical skin lesion severity in the TNCB-sensitized mice increased gradually with time (Figure 4). All mice in the positive control group (TNCB only) exhibited AD-like skin lesions comprising redness/scratch marks, edema/lichenification/thickening, hemorrhage/scabbing, erosion and desquamation (Figure 5). However, in the negative control mice (untreated), no superficial lesions were observed throughout the experimental period. After 8 days of assessment, the therapeutic efficacy of $0.1 \%$ doxycycline ointment became apparent and persisted throughout the experimental period. Although its efficacy was approximately equal to that of $0.1 \%$ betamethasone ointment until the 15 th day after commencement of assessment, it gradually weakened thereafter (Figures 4 and 5). On the other hand, topical application of vehicle only had no effect on the development of dermatitis.

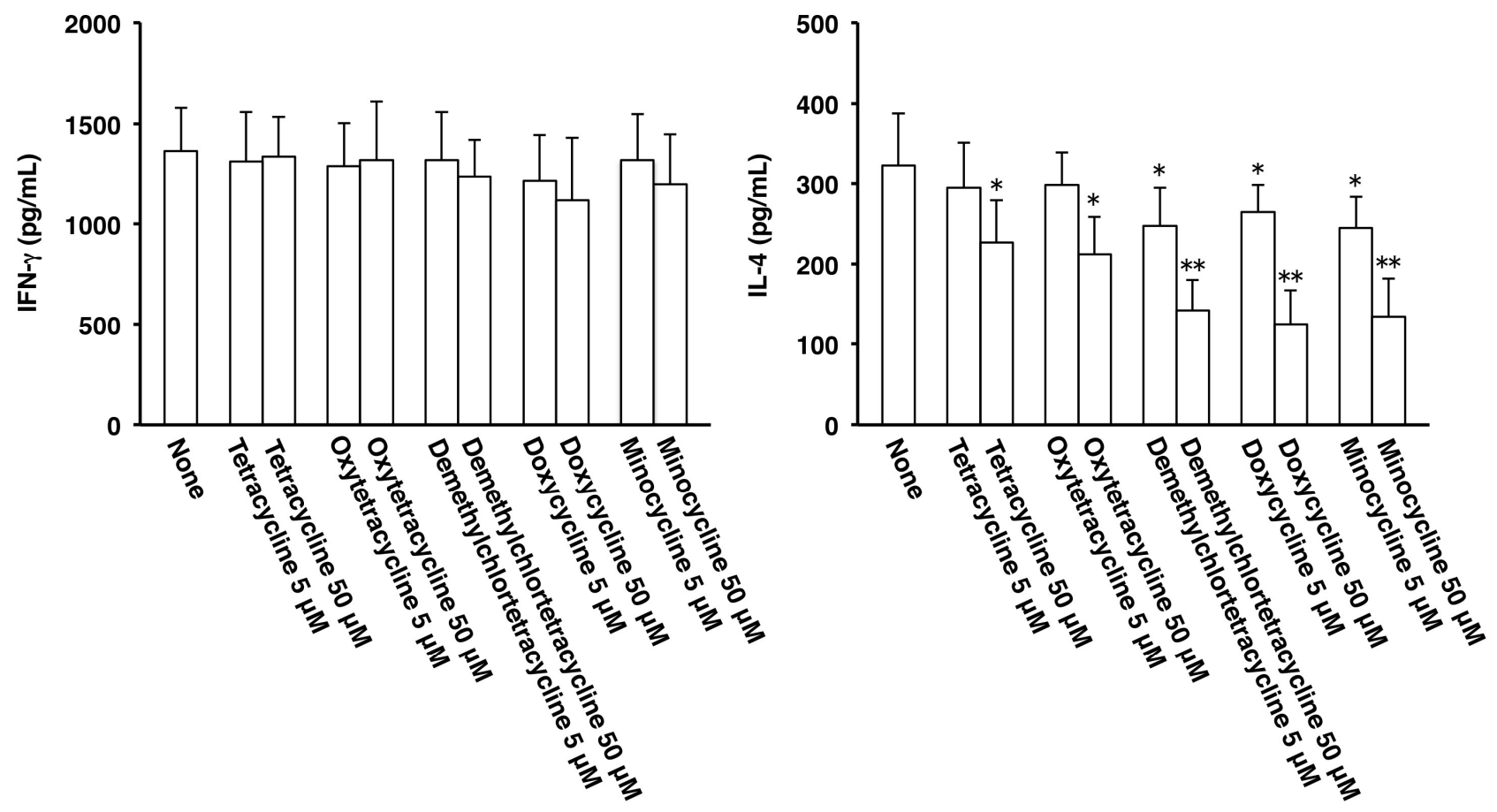

Figure 1. Effects of tetracycline antibiotics on development of Th1 and Th2 cells mediated by LCs. LCs were pulsed with OVA peptide for $18 \mathrm{~h}$ in the presence or absence of 5 and $50 \mu \mathrm{M}$ tetracycline, oxytetracycline, demethylchlortetracycline, doxycycline or minocycline. The OVA peptide-pulsed LCs were then injected into the hind footpads of mice, and popliteal lymph node cells were harvested 5 days later. Lymph node cells were stimulated through surface CD3/CD28 molecules, and the IFN- $\gamma$ and IL-4 concentrations in the culture supernatants were determined by ELISA. The results are expressed as means $\pm \mathrm{SD}(\mathrm{n}=6)$. ${ }^{*} P<0.05, * * P<0.01$ versus non-treatment. 


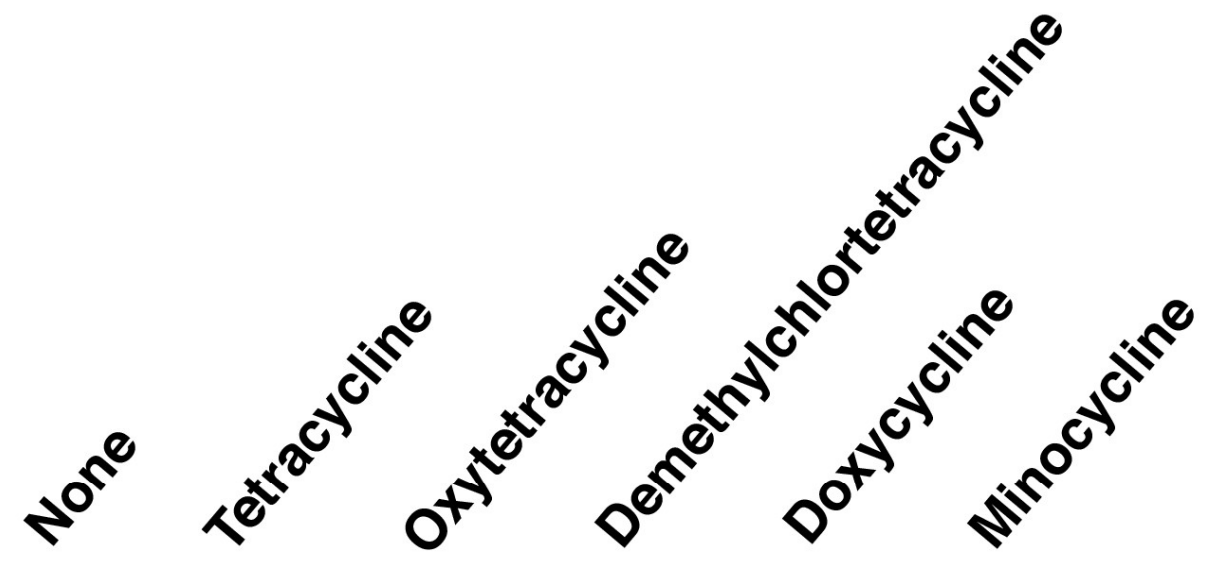

$\beta$-actin

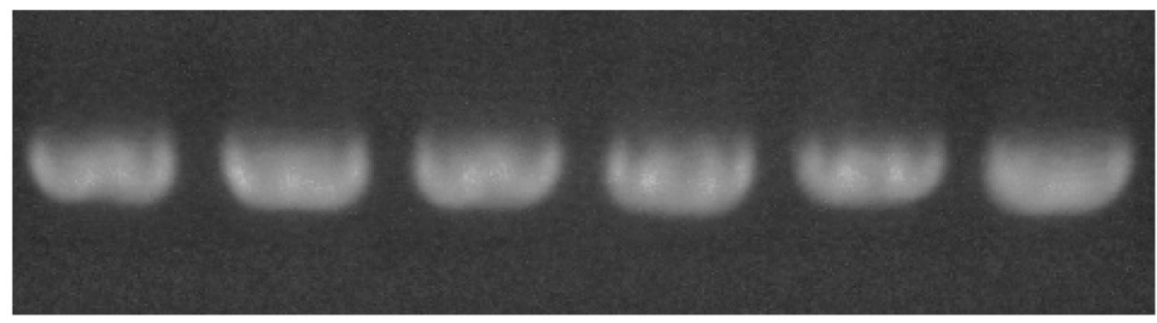

Jagged 1

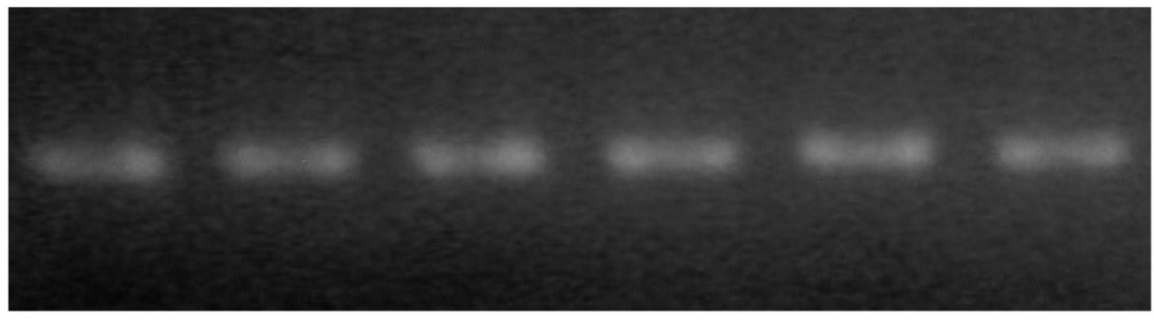

\section{Jagged 2}

\section{TIM-4}

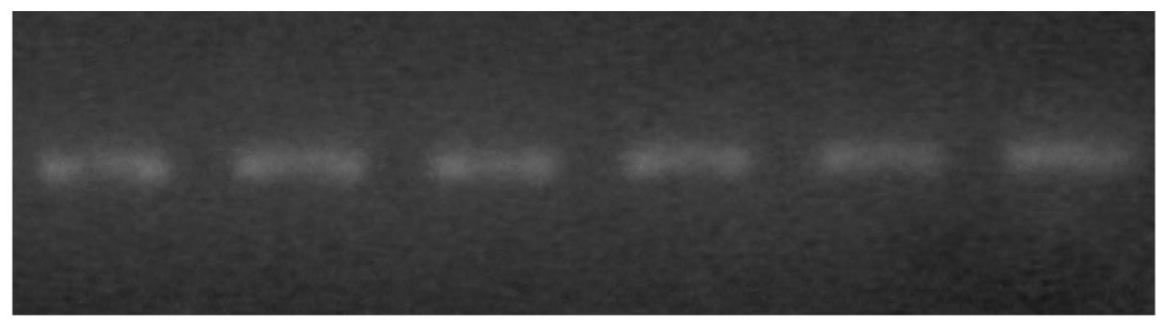

Figure 2. Effects of tetracycline antibiotics on cell surface molecule mRNA expression in LCs. LCs were pulsed with OVA peptide for $18 \mathrm{~h}$ in the presence or absence of $50 \mu \mathrm{M}$ tetracycline, oxytetracycline, demethylchlortetracycline, doxycycline or minocycline. Cytoplasmic mRNA was extracted from LCs, reverse-transcribed and amplified by PCR using $\beta$-actin, Jagged 1, Jagged 2 and TIM- 4 primer sets. The data shown are the representative results of 4 independent experiments. 


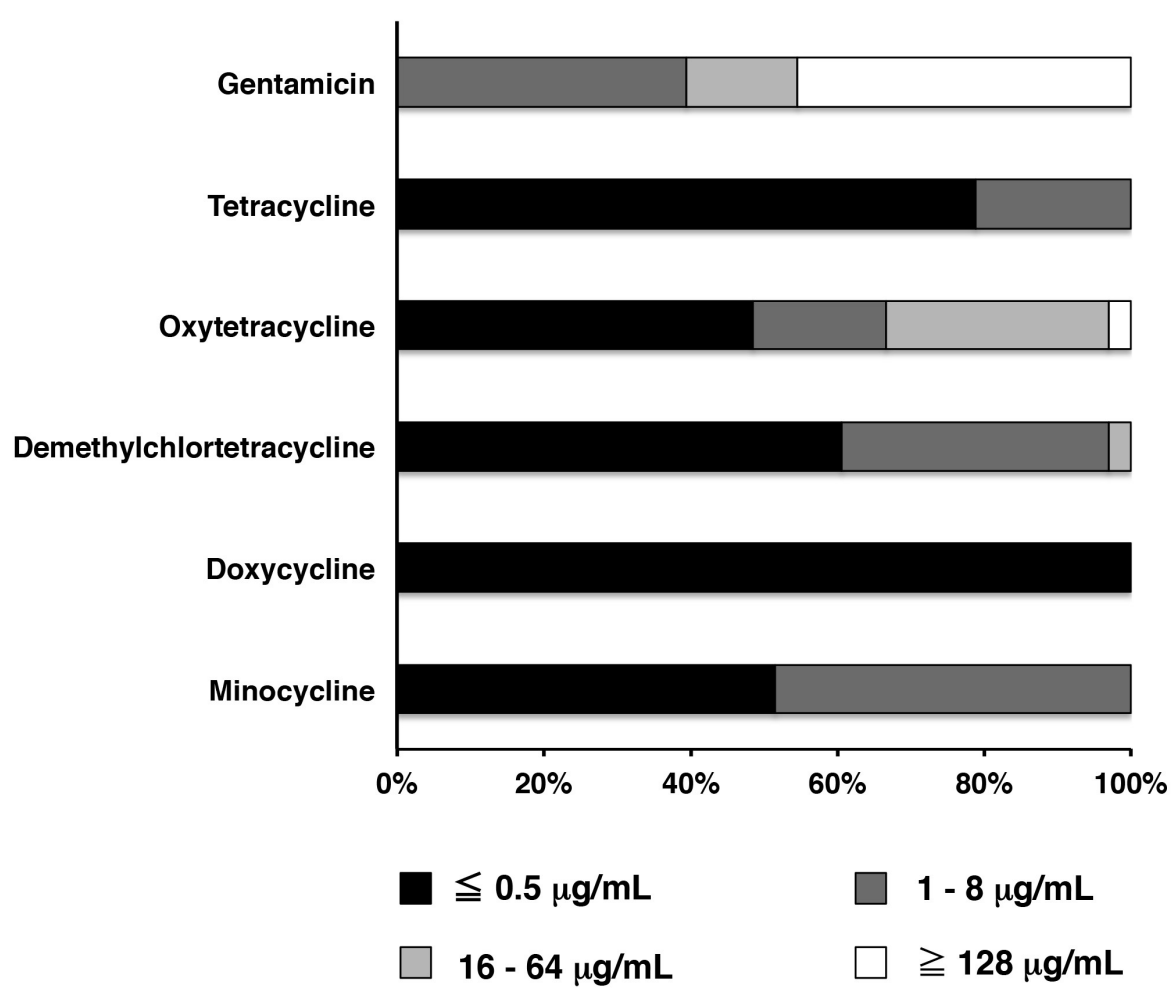

Figure 3. Susceptibility of $S$. aureus strains isolated from AD patients to gentamicin and tetracycline antibiotics. The susceptibility of 33 strains of $S$. aureus to each antibiotic was compared by estimating the MIC. The number of $S$. aureus strains with each corresponding MIC value is expressed as a percentage of the 33 strains.

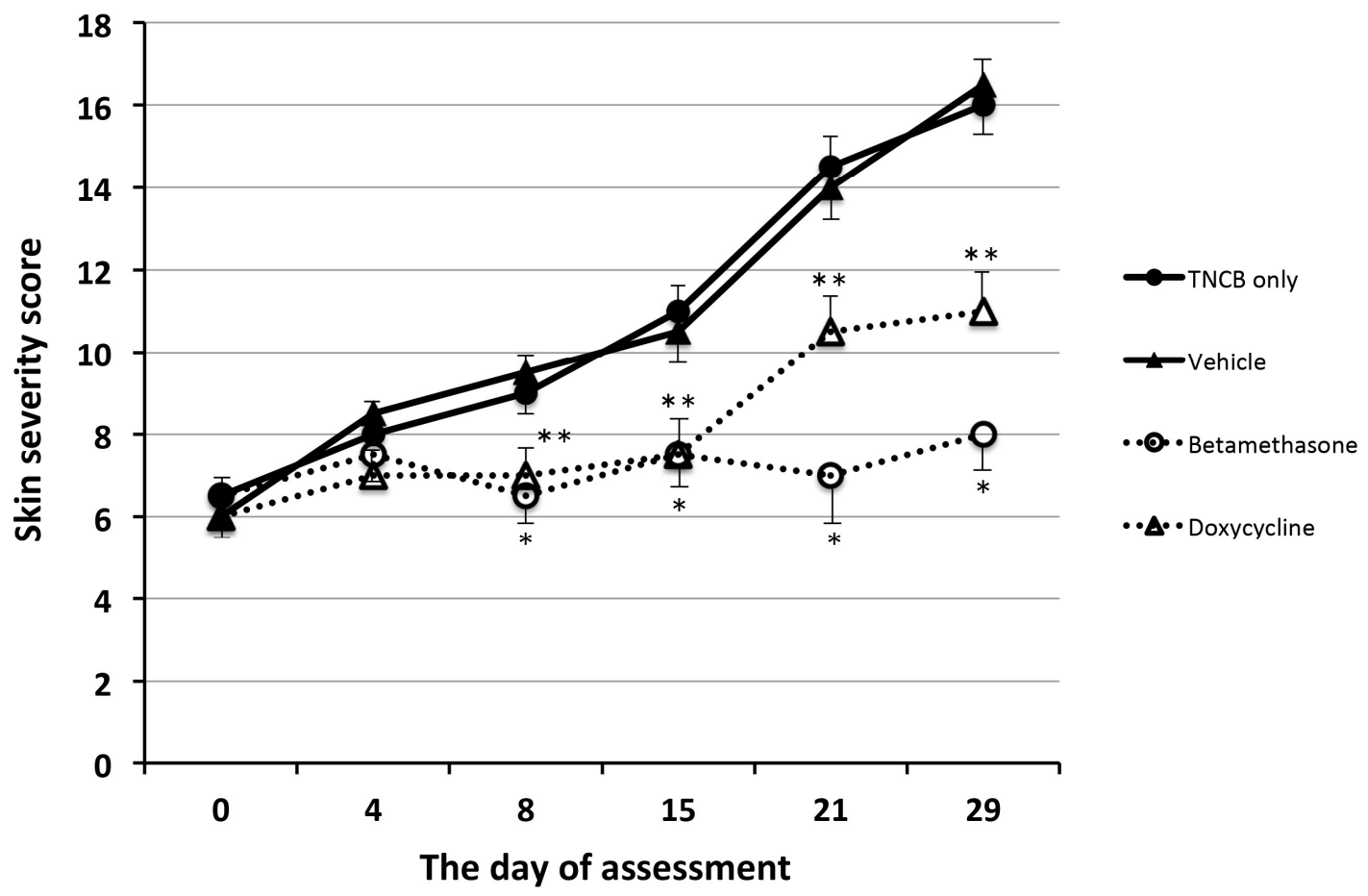

Figure 4. Effects of topical application of betamethasone and doxycycline on skin severity score. The results for each experimental group are expressed as means $\pm \mathrm{SD}(\mathrm{n}=6)$. $* P<0.01, * * P<0.01$ versus TNCB only. 


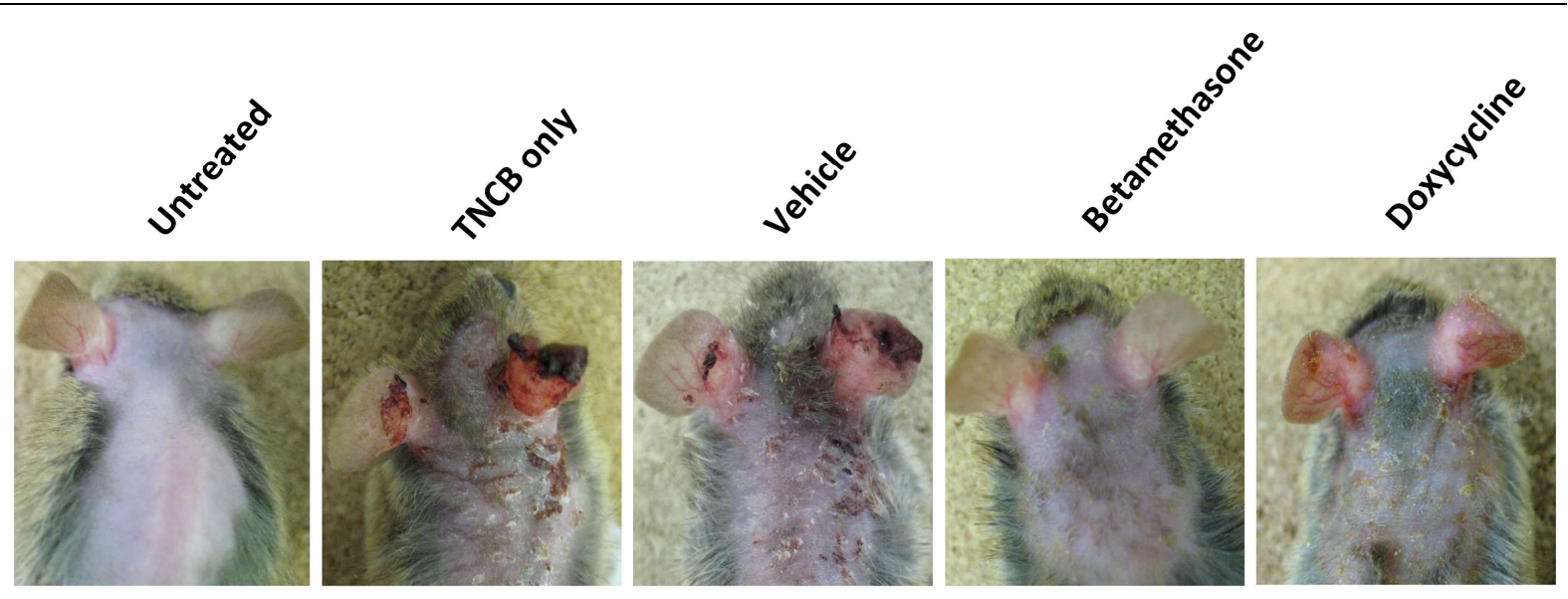

Figure 5. Macroscopic features of AD-like skin lesions in NC/Nga mice. The photograph shows skin lesions on the 29th day of assessment.

\section{Effects of Topical Application of Doxycycline on Histopathological Changes in Dorsal Skin}

As shown in Figure 6A, no abnormal histopathological changes were observed in the dorsal skin of negative control mice (untreated). However, after 29 days of assessment of skin lesion severity, positive control mice (TNCB only) showed epidermal hyperplasia and dense infiltration of inflammatory cells such as mast cells, eosinophils and lymphocytes, similar to that in skin lesions of AD patients. Topical application of vehicle only had no influence on these histopathological changes, whereas topical application of $0.1 \%$ doxycycline ointment had an inhibitive effect. However, the level of inhibition elicited by doxycycline was slightly inferior to that of betamethasone. The difference in the inhibitive effect between doxycycline and betamethasone was specifically remarkable in terms of the number of mast cells (Figure 6B).

\section{Effects of Topical Application of Doxycycline on Serum Total IgE Levels}

Serum total IgE levels on the 29th day of assessment of skin lesion severity were significantly elevated in positive control mice (TNCB only) (Figure 7). Although the increased concentration of $\operatorname{IgE}$ in serum was not reduced by topical application of vehicle, it was reduced significantly by application of betamethasone and doxycycline, respectively. Moreover, the level of reduction elicited by both drugs was almost the same.

\section{Effects of Topical Application of Doxycycline on Expression of IFN- $\gamma$ and IL-4}

The expression of mRNA for IFN- $\gamma$ and IL-4 in auricular lymph node cells and dorsal skin of negative control mice (untreated) was below the detection limit (Figure 8A, B). However, positive control mice (TNCB only) showed expression of IFN- $\gamma$ and IL-4 mRNA in both lymph node cells and skin. Although topical application of vehicle only had no influence on this mRNA expression, topical application of $0.1 \%$ betamethasone ointment inhibited it; topically applied $0.1 \%$ doxycycline ointment inhibited the expression of only IL-4 mRNA, and not that of IFN- $\gamma$ mRNA. In addition, using ELISA and immunohistological analysis, we examined whether expression of mRNA for IFN- $\gamma$ and IL-4 in lymph node cells and skin lesions was correlated with the synthesis of cytokine protein. ELISA for IFN- $\gamma$ and IL-4 was carried out using culture supernatants of lymph node cells that had been stimulated through surface $\mathrm{CD} 3 / \mathrm{CD} 28$ molecules for $48 \mathrm{~h}$. Figure $8 \mathrm{C}$ shows that IFN- $\gamma$ and IL-4 production from lymph node cells was significantly increased by TNCB treatment and suppressed by treatment with betamethasone, but not by vehicle, and that doxycycline treatment inhibited only IL-4 production. Figure 8D shows that TNCB treatment induced cells that were positive for IFN- $\gamma$ and IL-4 protein in the dermis, and that betamethasone but not vehicle suppressed the infiltration of these cells. However, doxycycline treatment inhibited the infiltration of only IL-4 protein-positive cells to a similar extent as betamethasone. HE staining of the skin suggested that the possible source of each cytokine was mainly $\mathrm{T}$ lymphocytes (data not shown). 
(A)
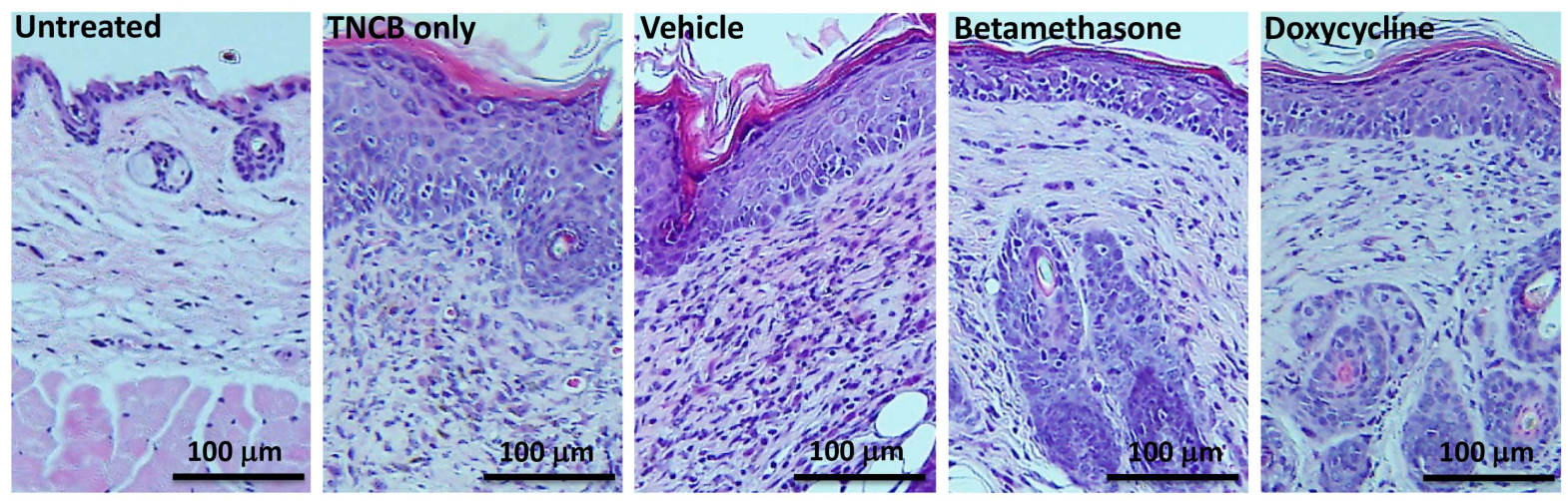

(B)
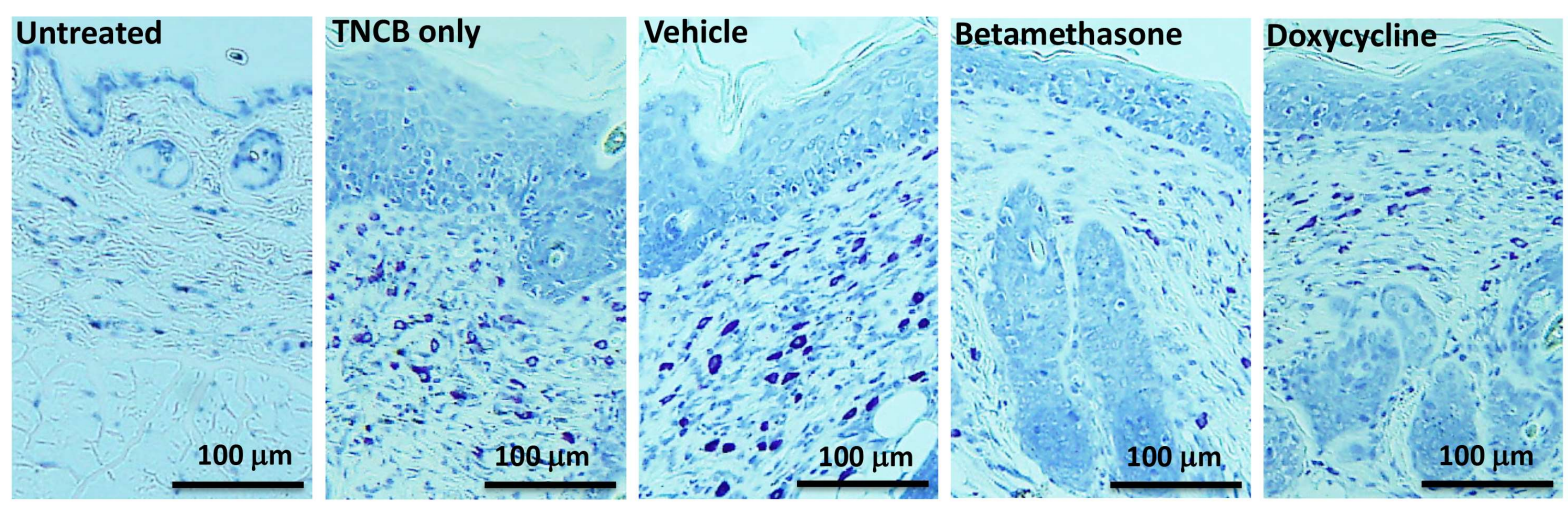

Figure 6. Histopathological analysis of AD-like skin lesions in NC/Nga mice. Skin sections were stained with hematoxylin-eosin (A) and toluidine blue (B) and observed at $\times 100$. The photograph shows sections of skin lesions on the 29th day of assessment.

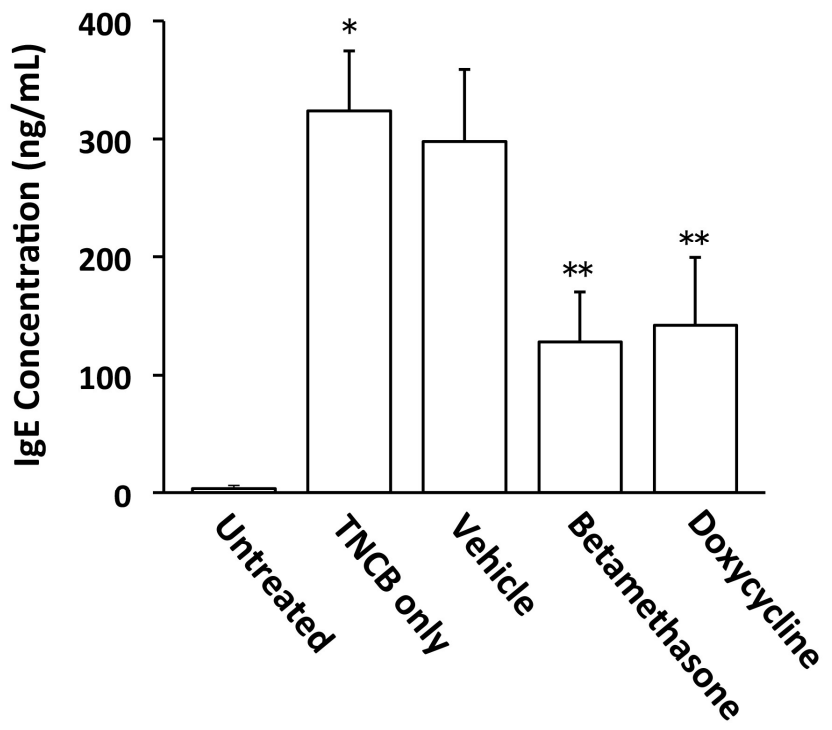

Figure 7. Quantification of IgE concentration in the serum of NC/Nga mice with AD-like skin lesions. The serum total IgE levels on the 29th day of assessment were measured by ELISA. The results for each experimental group are expressed as means $\pm \mathrm{SD}(\mathrm{n}=6) . * P<0.01$ versus untreated, $* * P<0.01$ versus TNCB only. 
(A)

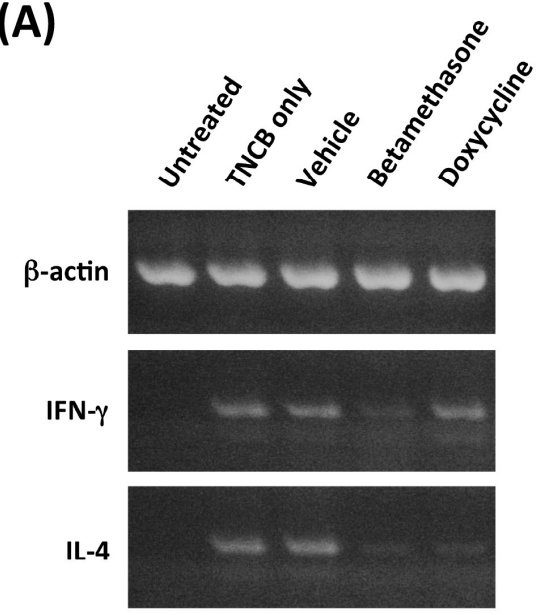

(B)

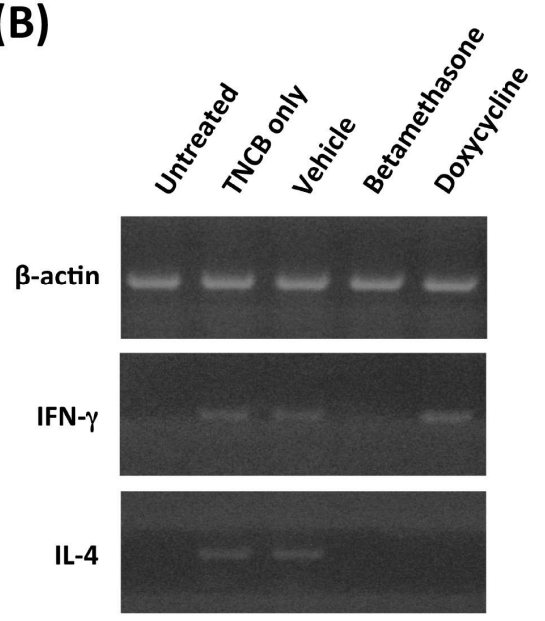

(C)

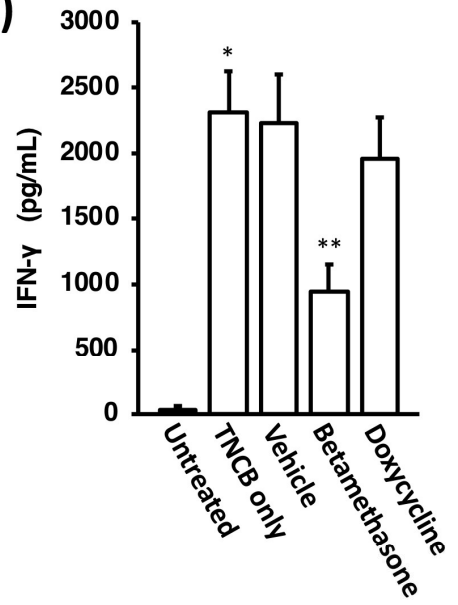

(D)

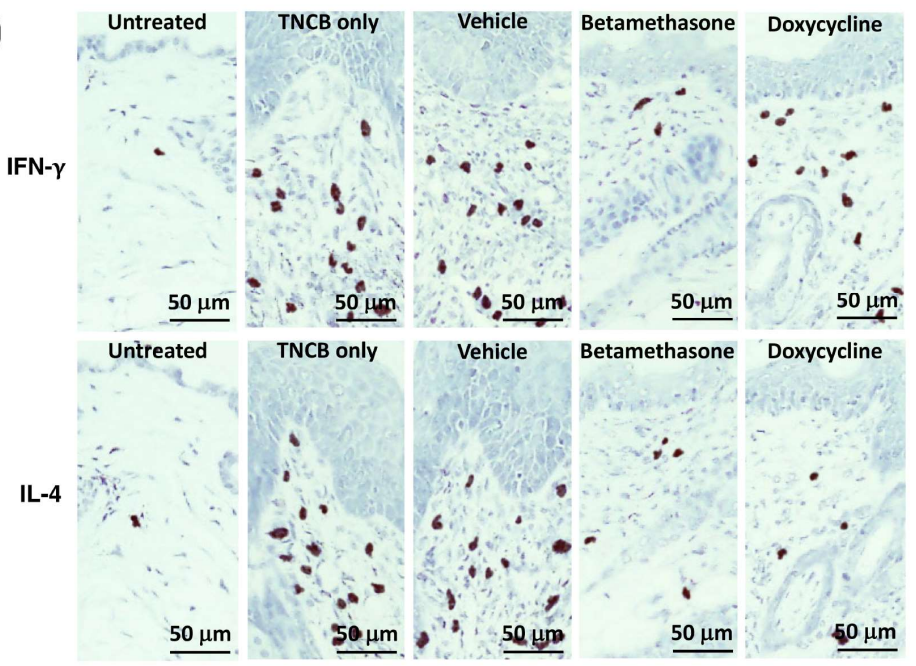

Figure 8. Effects of topical application of betamethasone and doxycycline on IFN- $\gamma$ and IL-4 expression in auricular lymph node cells and skin lesions of NC/Nga mice with AD-like skin lesions. mRNA was extracted from auricular lymph node cells (A) and skin lesions (B) of NC/Nga mice on the 29th day of assessment of skin severity, reverse-transcribed and amplified by PCR using primer sets for $\beta$-actin, IFN- $\gamma$ and IL-4. The data shown are representative results of six independent experiments. (C) Auricular lymph node cells on the 29th day of assessment of skin severity were stimulated through their surface CD3/CD28 molecules, and the IFN- $\gamma$ and IL-4 concentrations in the culture supernatants were determined by ELISA. Each culture was prepared in triplicate, and the mean value was obtained as a representative result for one experiment. The results are expressed as means $\pm \mathrm{SD}(\mathrm{n}=6) .{ }^{*} P<0.01$ versus untreated, ${ }^{* *} P<0.01$ versus TNCB only. (D) Skin sections on the 29th day of assessment of skin severity were stained with biotinylated monoclonal antibodies against IFN- $\gamma$ and IL- 4 , and observed at $\times 100$. Positive staining of cells is indicated by dark brown coloration.

\section{DISCUSSION}

Th1/Th2 immune balance has a close relationship with various immunological diseases including allergy. Many investigators have revealed that Th2 immunity is responsible for allergic immune responses and the subsequent pathogenesis of allergic inflammatory diseases (19-21). AD is also one such allergic disease, and the number of Th2 cells is markedly increased in both the peripheral blood and acute skin lesions of AD patients (1). Therefore, it has been proposed that Th2-type immune responses play a key pathogenetic role in $\mathrm{AD}$, and this is supported by the presence of blood eosinophilia and enhanced serum IgE levels in most AD patients (22). However, no immunoregulatory 
method for prevention of Th2 cell development in $\mathrm{AD}$ patients has yet been established.

In the present study, we observed that injection of LCs which had been treated with tetracycline antibiotics led to suppressed production of the Th2 cytokine IL-4, but not that of the Th1 cytokine IFN$\gamma$ in lymph node cells of mice. Since each antibiotic was washed out before the LCs were injected, it was reasonable to assume that each antibiotic acted on LCs and changed their function. In mammals, four Notch receptors, Notch 1-4, and five Notch ligands, Delta 1, Delta 3, Delta 4, Jagged 1 and Jagged 2, have been identified (23). Amsen et al. (24) have presented evidence that different Notch ligands expressed on APCs instruct Th1/Th2 differentiation in mice, and have concluded that Th1 adjuvant induces Th1 differentiation through the expression of Delta members in APCs, while Th2 adjuvant induces Th2 differentiation through the expression of Jagged members. Furthermore, TIM-4 is expressed by DCs in lymphoid organs, and its ligand, TIM-1, is expressed by $\mathrm{T}$ cells. These molecules have been found to be critical regulators of Th2 differentiation (25) and we have also confirmed this in our previous study (17). Therefore, to clarify the mechanisms underlying the down-regulation of Th2 cell development induced by tetracycline antibiotics, expression of mRNA for Jagged 1, Jagged 2, and TIM-4 in LCs and the influence of tetracycline antibiotics were confirmed by RT-PCR. Our results showed that mRNA for Jagged 1, Jagged 2, and TIM-4 was expressed spontaneously in LCs and that only TIM-4 mRNA expression was suppressed by treatment with tetracycline antibiotics. Moreover, the levels of TIM-4 mRNA expression were well correlated with inhibition of $\mathrm{Th} 2$ cell development, and especially demethylchlortetracycline, doxycycline and minocycline had a superior inhibitory effect on TIM-4 mRNA expression and Th2 cell development relative to tetracycline and oxytetracycline.

On the other hand, examination of the susceptibility of $S$. aureus strains isolated from the lesional skin of $\mathrm{AD}$ patients to tetracycline antibiotics revealed that doxycycline had the strongest antibacterial activity relative to gentamicin, which is used widely in Japan in combination with steroids for topical application in $\mathrm{AD}$, as well as other tetracycline antibiotics. Therefore, doxycycline appears to be unique in that it not only has superior antibacterial action against $S$. aureus but is also able to control Th2 cell development.

The next step of this study was to investigate the effect of doxycycline on AD. Our data demonstrated that topical application of doxycycline markedly ameliorated AD-like skin lesions in $\mathrm{NC} / \mathrm{Ng}$ mice. In comparison to the vehicle control group, skin lesion severity assessed macroscopically in terms of redness/scratch marks, edema/lichenification/thickening,

hemorrhage/scabbing, erosion and desquamation was significantly decreased by application of $0.1 \%$ doxycycline ointment. Although, this suppressive effect was equal to that of betamethasone, which has been used widely in Japan for topical treatment of $\mathrm{AD}$, until the 15th day after commencement of assessment, it gradually weakened thereafter in comparison with betamethasone. These findings were also supported by histopathologic analysis. Topical application of doxycycline inhibited epidermal hyperplasia and dense infiltration of inflammatory cells such as mast cells, eosinophils and lymphocytes, although to a slightly inferior degree relative to betamethasone. The difference in the reduction of the number of mast cells was particularly noticeable. Our present study showed that LCs treated with doxycycline inhibited Th2 cell development in lymph nodes through downregulation of TIM-4 expression in LCs. Therefore, it was thought that topical application of doxycycline to skin lesions of NC/Nga mice affected LCs in the epidermis, which then moved to lymph nodes, where Th2 cell development and subsequent IL-4 production were down-regulated. Furthermore, elevation of IFN- $\gamma$ and IL-4 expression in TNCBtreated $\mathrm{NC} / \mathrm{Nga}$ mice was observed in skin lesions, similarly to the situation in human AD lesions (22), and topical application of doxycycline inhibited the expression of IL-4, but not that of IFN- $\gamma$. It seems that the levels of these cytokines might mirror those in lymph nodes, as the Th1 cell marker, CCR5, and its ligand CCL3/macrophage inflammatory protein (MIP)-1 $\alpha$, are strongly expressed in skin lesions of NC/Nga mice $(26,27)$. Furthermore, the Th2 cell marker, CCR4, and its ligands CCL17/thymus and activation-regulation chemokine (TARC) and CCL22/monocyte-derived chemotactic cytokine (MDC), are also highly expressed in AD skin lesions. Therefore, Th1 and Th2 cells in the skin lesions of TNCB-treated NC/Nga mice would be derived from lymph node cells. It is known that the $\mathrm{Th} 2$ cytokine response is dominant in the acute phase of $\mathrm{AD}$, and also in the late phase the Th1 cytokine response is increased in addition to the Th2 cytokine response, contributing to chronic inflammation $(1,22,28)$. These facts indicate that topical application of 
doxycycline can regulate acute inflammation in particular, thus contributing to amelioration of early AD-like skin lesions in $\mathrm{NC} / \mathrm{Ng}$ mice.

Around $70-80 \%$ of patients with AD show increased serum levels of IgE, which are associated with disease severity (1). Elevation of serum $\mathrm{IgE}$ levels was also observed in TNCB-treated NC/Nga mice, and topical application of doxycycline significantly reduced the serum $\operatorname{IgE}$ concentration as effectively as betamethasone. IL-4 receptormediated signaling in B cells is essential for induction of IgE synthesis (29). Therefore, elevation of serum IgE levels in TNCB-treated NC/Nga mice and its inhibition by topical application of doxycycline could be explained by the degree of IL4 expression in lymph nodes.

The data from this study suggest that doxycycline may have excellent ability to inhibit $\mathrm{Th} 2$ cell development in AD patients. Furthermore, we have shown that $S$. aureus strains isolated from the lesional skin of $\mathrm{AD}$ patients were susceptible to doxycycline. Since the skin of most AD patients shows superficial $S$. aureus colonization and barrier disruption due to a decrease of filaggrin (30), bacterial products such as staphylococcal enterotoxins, lipoteichoic acid and peptidoglycan would be expected to penetrate the skin and induce the production of Th2 cells and chemokines, which in turn would induce a Th2 immune response and augment skin inflammation (1, 4-6, 31-33). Therefore, topical application of doxycycline to the lesioned skin of $\mathrm{AD}$ patients appears to exert an excellent effect involving a bactericidal action against $S$. aureus and inhibition of the Th2 immune response in lesioned skin by inhibiting the development of LC-mediated allergen-specific Th2 cells, unlike immunosuppressants such as tacrolimus, or steroids. Since it is thought that topical application of doxycycline to the skin has few side effects, it might be possible to increase its concentration in ointment to a level that would more strongly inhibit Th2 cell development in AD patients and the subsequent Th2 immune response in $\mathrm{AD}$ lesions.

\section{CONCLUSUIONS}

Our results have demonstrated that topical application of doxycycline inhibits the development of AD-like skin lesions and the Th2 immune response in $\mathrm{NC} / \mathrm{Nga}$ mice. Thus, topical administration of doxycycline might be beneficial and preferable to betamethasone as a new therapeutic strategy for acute AD lesions with superficial S. aureus colonization.

\section{ACKNOWLEDGEMENTS}

This work was supported by JSPS KAKENHI Grant Number 17K08469.

\section{CONFLICT OF INTEREST}

The authors have no conflicts of interest to declare.

\section{REFERENCES}

1. Leung DY, Boguniewicz M, Howell MD, Nomura I, Hamid QA. New insights into atopic dermatitis. J Clin Invest, 2004; 113: 651-657. DOI: $10.1172 / \mathrm{JCI} 21060$

2. Guzik TJ, Bzowska M, Kasprowicz A, CzerniawskaMysik G, Wójcik K, Szmyd D, Adamek-Guzik T, Pryjma J. Persistent skin colonization with Staphylococcus aureus in atopic dermatitis: relationship to clinical and immunological parameters. Clin Exp Allergy, 2005; 35: 448-455. DOI: $10.1111 / j .1365-2222.2005 .02210 . x$

3. Matsui K, Nishikawa A, Suto H, Tsuboi R, Ogawa H. Comparative study of Staphylococcus aureus isolated from lesional and non-lesional skin of atopic dermatitis. Microbiol Immunol, 2000; 44: 945-947. DOI: $10.1111 / \mathrm{j} .1348-0421.2000 . t b 02587 . x$

4. Matsui K, Nishikawa A. Peptidoglycan from Staphylococcus aureus induces Th2 immune response in mice. J Investig Allergol Clin Immunol, 2012; 22: 80-86.

5. Matsui K, Nishikawa A. Peptidoglycan-induced T helper 2 immune response in mouse involves interleukin-10 secretion from Langerhans cells. Microbiol Immunol, 2013; 57: 130-138. DOI: 10.1111/j.1348-0421.2012.12006.x

6. Matsui K, Ikeda R. Peptidoglycan in combination with muramyldipeptide synergistically induces an interleukin-10-dependent $\mathrm{T}$ helper 2-dominant immune response. Microbiol Immunol, 2014; 58: 260-265. DOI: 10.1111/1348-0421.12139

7. Banchereau J, Steinman RM. Dendritic cells and the control of immunity. Nature, 1998; 392: 245-252. DOI: $10.1038 / 32588$

8. Katz SI, Tamaki K, Sachs DH. Epidermal Langerhans cells are derived from cells originating in bone marrow. Nature, 1979; 282: 324-326. DOI: $10.1038 / 282324 \mathrm{a} 0$

9. De Fraissinette A, Schmitt D, Thivolet J. Langerhans cells of human mucosa. J Dermatol, 1989; 16: 255262. DOI: $10.1111 /$ j.1346-8138.1989.tb01261.x

10. Barrett AW, Cruchley AT, Williams DM. Oral mucosal Langerhans' cells. Crit Rev Oral Biol Med, 1996; 7: 36-58. 
11. MacPherson GG, Liu LM. Dendritic cells and Langerhans cells in the uptake of mucosal antigens. Curr Top Microbid Immunal, 1999; 236: 33-53. DOI: 10.1007/978-3-642-59951-4_3

12. Steinman R, Inaba K. Immunogenicity: role of dendritic cells. Bioessays, 1989; 10: 145-152. DOI: 10.1002/bies.950100503

13. Lanzavecchia A, Sallusto F. Dynamics of $T$ lymphocyte responses: intermediates, effectors, and memory cells. Science, 2000; 290: 92-97. DOI: 10.1126/science.290.5489.92

14. Okamoto $\mathrm{T}$, Iwata $\mathrm{S}$, Ohnuma $\mathrm{K}$, Dang $\mathrm{NH}$, Morimoto C. Histamine H1-receptor antagonists with immunomodulating activities: potential use for modulating $\mathrm{T}$ helper type 1 (Th1)/Th2 cytokine imbalance and inflammatory responses in allergic diseases. Clin Exp Immunol, 2009; 157: 27-34. DOI: 10.1111/j.1365-2249.2009.03958.x

15. Matsui K, Mori A, Ikeda R. Langerhans cells-like dendritic cells stimulated with an adjuvant direct the development of Th1 and Th2 cells in vivo. Clin Exp Immunol, 2015; 182: 101-107. DOI: 10.1111/cei.12671

16. Monk E, Shalita A, Sieqel DM. Clinical application of non-antimicrobial tetracyclines in dermatology. Pharmacol Res, 2011; 63: 130-145. DOI: 10.1016/j.phrs.2010.10.007

17. Matsui K, Tamai S, Ikeda R. Effects of macrolide antibiotics on Th1 cell and Th2 cell development mediated by Langerhans cells. J Pharm Pharm Sci, 2016; 19: 357-366. DOI: 10.18433/J3Z32F

18. Matsui K, Tachioka K, Onodera K, Ikeda R. Topical application of josamycin inhibits development of atopic dermatitis-like skin lesions in NC/Nga mice. J Pharm Pharm Sci, 2017; 20: 38-47. DOI: 10.18433/J3GW3D

19. Kay AB. Allergy and allergic diseases - first of two parts. N Engl J Med, 2001; 344: 30-37. DOI: 10.1056/NEJM200101043440106

20. Herrick CA, Bottomly K. To respond or not to respond: T cells in allergic asthma. Nat Rev Immunol, 2003; 3: 405-412. DOI: 10.1038/nri1084

21. Nguyen TH, Casale TB. Immune modulation for treatment of allergic disease. Immunol Rev, 2011; 242: $\quad 258-271$. DOI: $\quad 10.1111 / \mathrm{j} .1600$ 065X.2011.01034.X

22. Grewe M, Bruijnzeel-koomen CAFM, Schöpf E, Thepen T, Langeveld-Wildschut AG, Ruzicka T, Krutmann J. A role of Th1 and Th2 cells in the immunopathogenesis of atopic dermatitis. Immunol
Today, 1998; 19: 359-361. DOI: 10.1016/S01675699(98)01285-7

23. Artavanis-Tsakonas S, Rand MD, Lake RJ. Notch signaling: cell fate control and signal integration in development. Science, 1999; 284: 770-776. DOI: 10.1126/science. 284.5415 .770

24. Amsen D, Blander JM, Lee GR, Tanigaki K, Honjo T, Flavell RA. Instruction of distinct CD4 T helper cell fates by different Notch ligands on antigenpresenting cells. Cell, 2004; 117: 515-526. DOI: 10.1016/S0092-8674(04)00451-9

25. Ruiter B, Shreffler WG. The role of dendritic cells in food allergy. J Allergy Clin Immunol, 2012; 129: 921-928. DOI: 10.1016/j.jaci.2012.01.080

26. Terada M, Tsutsui H, Imai Y, Yasuda K, Mizutani H, Yamanishi K, Kubo M, Matsui K, Sano H, Nakanishi K. Contribution of IL-18 to atopic-dermatitis-like skin inflammation induced by Staphylococcus aureus product in mice. Proc Natl Acad Sci USA, 2006; 103: 8816-8821. DOI: 10.1073/pnas.0602900103

27. Vestergaard C, Yoneyama H, Murai H, Nakamura K, Tamaki K, Terashima Y, Imai T, Yoshie O, Irimura T, Mizutani H, Matsushima K. Overproduction of Th2specific chemokines in NC/Nga mice exhibiting atopic dermatitis-like lesions. J Clin Invest, 1999; 104: 1097-1105. DOI: 10.1172/JCI7613

28. Sabin BR, Peters N, Peters AT. Chapter 20: atopic dermatitis. Allergy Asthma Proc, 2012; 33 (Suppl 1): S67-69. DOI: 10.2500/aap.2012.33.3553

29. Wu LC, Scheerens H. Targeting IgE production in mice and humans. Curr Opin Immunol, 2014; 31: 815. DOI: 10.1016/j.coi.2014.08.001

30. Brown SJ, McLean WH. One remarkable molecule: filaggrin. J Invest Dermatol, 2012; 132: 751-762. DOI: $10.1038 /$ jid.2011.393

31. Matsui K, Nishikawa A. Lipoteichoic acid from Staphylococcus aureus induces Th2-prone dermatitis in mice sensitized percutaneously with an allergen. Clin Exp Allergy, 2002; 32: 783-788. DOI: 10.1046/j.1365-2222.2002.01357.x

32. Matsui $\mathrm{K}$, Wirotesangthong $\mathrm{M}$, Nishikawa $\mathrm{A}$. Percutaneous application of peptidoglycan from Staphylococcus aureus induces eosinophil infiltration in mouse skin. Clin Exp Allergy, 2007; 37: 615-622. DOI: $10.1111 /$ j.13652222.2007.02673.x

33. Matsui K, Nishikawa A. Percutaneous application of peptidoglycan from Staphylococcus aureus induces infiltration of $\mathrm{CCR}^{+}$cells into mouse skin. J Investig Allergol Clin Immunol, 2011; 21: 354-362. 
Supplementary Figure including all RT-PCR traces.
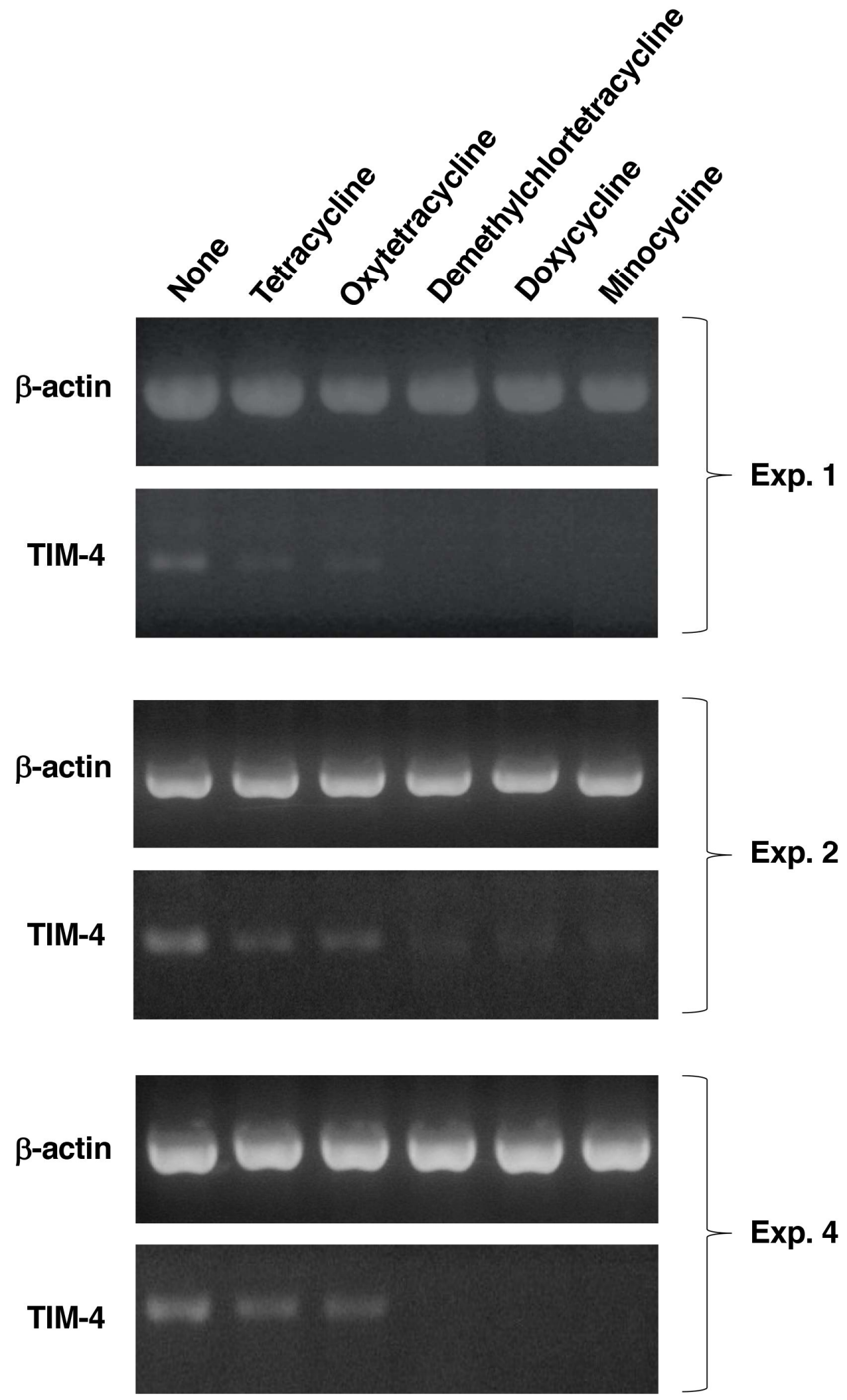